\title{
The Cultivation Path of Artisans in Applied Institutes
}

\author{
Sun Zeyang ${ }^{1}$ \\ ${ }^{1}$ yingkou Institute of Technology, Yingkou, Liaoning, 115014
}

Keywords: applied undergraduate colleges; artisan spirit; cultivation path

\begin{abstract}
Artisan spirit is of great significance to talent cultivation in applied undergraduate colleges. Based on the analysis of the connotation of artisan spirit and the characteristics of applied undergraduate colleges, this paper explores the cultivation path of artisan spirit of applied undergraduate colleges. First, strengthening the top-level design and carrying forward the spirit of artisans; Second, attaching importance to the construction of teachers and upgrading the level of education; Third, relying on the integration of production and teaching to strengthen practice and education; Fourth, strengthening routine cultivation and optimizing the education environment.
\end{abstract}

\section{Introduction}

Since 2016, in two consecutive years of government work reports, Li Keqiang, premier of the State Council, has proposed to vigorously promote the spirit of artisans, strive to cultivate more artisans and talents and create more Chinese brands world-renowned.[1] In this context, to cultivate the spirit of artisans become the mission of the era of applied undergraduate colleges and universities, to accomplish this mission requires that applied undergraduate colleges and universities must carry forward the spirit of artisans to cultivate the application of skilled personnel for the positioning of running a school.

\section{The Analysis of Artisan Spirit}

The art of craftsman in our country has since ancient times, the pre-Qin "Kao Gong Ji" in the "hundred work, all saints" discourse, "Zhuangzi" in the "Chi Ding solution cattle, technology imminent" sigh, Southern Song Zhu Xi "rule Has been fine, and its essence and refinement, "the note, the stunning Jingdezhen ceramics, silk Jiangnan, the world marvelous terracotta warriors and horses, the Great Wall and many other examples, all reflect the spirit of ancient Chinese craftsmen. [1]

What is artisan spirit? At present, there is no clear definition of the academic community in our country. Based on the analysis of the relevant literature both at home and abroad, the author thinks that the spirit of craftsmen has developed into the present society and its meaning is constantly expanding. [2] The term artisan does not refer to the ancient artisans Summarized as dedicated, serious and determined professional people. Usually on the artisan spirit, including superb skills and superb skills, rigorous and meticulous, focused and responsible work attitude, crafted, the concept of excellence, as well as the identity of the profession, a sense of responsibility. When it becomes internalized, it becomes a professional ethic, becomes a natural manifestation in the course of professional career, and forms a professional accomplishment when it is transformed into an individual. It is an important measure of the identification of qualified personnel in an enterprise. In summary, I believe that the spirit of craftsmen belong to the category of professional accomplishments, is a comprehensive embodiment of professional skills, professionalism and professional attitude including dedication, excellence, focus on responsibility, innovation and so on.

\section{The Practical Significance of Application of Artisan Spirit in Undergraduate Colleges}

\subsection{It is an inevitable requirement for the social and economic development of our country}

In May 2015, the State Council formally issued "Made in China 2025" and proposed that the 
Chinese government implement the first decade of its plan of making a powerful nation a reality. It will realize the transformation from a manufacturing power to a manufacturing power and a leap forward from China's manufacturing to China's creation. [2] At present, if China wants to achieve the goal of creating a strong nation, making wise decisions by China and creating by China, and pushing economic development into a new era, a large number of highly-skilled talents with artisan spirit will be required. Under this background, the cultivation fits perfectly into the needs of the times and becomes inevitable.

\subsection{It is the mission of applied undergraduate colleges}

In February 2017, the Guidelines for the Development of Manufacturing Talents jointly prepared by the Ministry of Education, the Ministry of Human Resources and Social Security, the Ministry of Industry and Information Technology and other departments proposed that "we should promote the spirit of craftsmen into the campus and into the classroom so as to help students to establish lofty Professional career ideals and good professional ethics, cultivate respect for labor, dedication and trustworthiness, excellence, innovation and daring manufacturing talent."[2] Applied undergraduate colleges have the dual characteristics of higher education and vocational education, shouldering the mission of cultivating high-quality applied talents adapted to economic and social development, shouldering the historical responsibility of training artisans of great powers in the new era, and cultivating the spirit of artisans, And constantly improve the quality of personnel training in order to effectively meet the requirements of the manufacturing powerful strategy for personnel training.

\subsection{It is the objective needs of students to grow up}

Craftsman spirit is not only reflected in the manufacturing industry, it represents a "temperament", a spirit of concentration, conscientious, determined, the pursuit of excellence spirit. Some college students, it is the lack of this temperament, spent the most beautiful college time loss, seemingly busy, but in fact mediocre. [2] Therefore, the cultivation of artisan spirit to promote the growth of college students has a very crucial incentive. On the one hand, the artisan spirit provides powerful mental motivation for college students, stimulates their initiative in learning, hone their skills in innovative practice, and always maintains the tenacity of continuous improvement. On the other hand, they can inspire them to constantly break themselves, dare to face the challenges and difficulties, overcome impulsive psychology, devote themselves to learning the truth, and better to grow into an application-oriented talents in serving the community and forge a valuable life.

\section{The Cultivation Path to Explore Artisan Spirit in Applied Undergraduate Students}

The spirit of craftsman is the soul of professional accomplishment. The cultivation process is also the same as the cultivation of professional accomplishment. It belongs to cultivate education. The cultivation process is not accomplished in a single step. It is continuous, long-term and procedural. It requires the joint efforts of society, schools and families participate. To dedicate dedication, excellence, focus on responsibility, innovation and other outstanding elements into the fostering of the whole process, specifically divided into the following areas. [3]

\subsection{Strengthen the top-level design, carry forward the artisan spirit}

Applied undergraduate colleges and universities shoulder the heavy responsibility of cultivating the "big country artisans". In the process of cultivating the craftsmanship, we should pay attention to the concept of "all staff members, the whole process and the omni-directionality". First, we must change our educational philosophy and strengthen the top-level design. The colleges and universities should integrate the cultivation and promotion of artisans' spirit into the whole process of personnel training, imperceptibly infiltrating the cultivation of artisan spirit in the concepts, guidelines, school spirit, teaching style and style of study. Second, to promote craftsmanship, integration into the teaching process. Colleges and universities should combine the cultivation of artisan spirit with the various education and teaching links such as major construction, curriculum establishment, ideological and political education and practice practice so that the cultivation of 
"artisan spirit" and the cultivation of "big country artisans" as the consensus of values among college teachers and students are ubiquitous, forming a new situation of cultural people and educating people[3].

\subsection{Attach importance to the construction of teachers}

Teachers shoulder the sacred mission of evangelism to solve puzzles and assume the support and intellectual support for the building of an overall well-to-do society and economic and social development. In order to realize the school-running orientation of cultivating applied talents of "high level and distinctiveness" and realize the concept of running a school oriented to the needs of the society, service industries and local economy, the applied undergraduate colleges must emphasize their characteristics of running a school and attach importance to the teaching staff Construction. [3] First, it is necessary to build a strong and highly professional team of "double-teacher dual-capable" teachers. Colleges and universities to encourage professional teachers in-depth training to the enterprise line to enhance practical teaching. Second, highlighting the cultivation of "artisan spirit" in the teaching and training of specialized courses. Professional teachers should combine the characteristics of professional post, analyze the importance of having the craftsman spirit to the occupation, and the important role of students in the future development and the growth of talents. Dedicate and dedication in the "craftsman spirit" The profound meaning of innovation into the professional teaching and practical training, and include them in the assessment of students, so that the professional teaching of theoretical teaching and practical training more connected, more dynamic. Third, to achieve a two-way school-enterprise opening up and mutual recruitment of talents. University teachers can work in enterprises, senior professionals in the enterprise, senior engineers and researchers in research institutes can also participate in the teaching and research of colleges and universities as external teachers, external tutors and visiting professors. While practicing students' practical ability and professional skills, they lead the students through the role model and professionalism of students, and make students contact with society, industries and enterprises, understand the requirements of industry and enterprises on the professional accomplishment of employees, and experience in practice The importance of "craftsmanship" in his career.

\subsection{Relying on the integration of industry and education, strengthen the practice of educating students}

Colleges and universities should carry out the cultivation and practice of artisan spirit with the cooperation between school and enterprise as well as the integration of production and teaching so as to make them internalized as the spiritual strength for students to grow and become talents. First, strengthen the cooperation between schools and enterprises to build a platform for the cultivation of artisan spirit. [3] The cultivation of artisan spirit alone is not enough to rely on colleges and universities, we must rely on enterprises to form a joint force. Through practice opportunities provided by enterprises, students can imperceptibly form good professional ethics, professional attitude and professional qualities in practical work positions. At the same time, students are allowed to recognize the influence of corporate culture on career development and guide students from students to professional roles Change. Second, bring together the "kinetic energy" of innovation and further promote innovation and entrepreneurship education reform. Innovation is the core element of artisan spirit and the technical support for our country to achieve the goal of "creating in China." Colleges and universities should always adhere to the innovation and entrepreneurship education and the cultivation of craftsmanship integration, and throughout the entire process of personnel training, through the organization of professional competitions, subject competitions, innovation and entrepreneurship competitions and other forms, in practice, cultivate students' awareness of innovation and enhance the level of innovation. Third, to explore "integration of production and education" and to integrate the cultivation of "craftsmanship" into the field of production. We should give full play to the application of undergraduate colleges and universities to serve the regional economic development of the school positioning in the professional settings and discipline development, to adapt to the needs of the development of the region's industry, and 
actively docking with enterprises in the curriculum, professional training for the enterprises in the region Standards, the school invited enterprises to participate in the development of personnel training programs, teaching materials, teaching and practice of the evaluation system.

\subsection{Strengthen daily nurturing, optimize the education environment}

Colleges and universities have a positive influence on the development of students 'personality. A good cultural atmosphere and education environment are the soul of a university education and are very important to the students' growth and life. First, taking "artisan spirit" as guiding ideology for educating people in colleges and universities, forming a good atmosphere for educating people and providing strong spiritual motivation for college students are very crucial motivating factors in promoting the growth of undergraduates. Second, with the help of implicit education, publicity and promotion of craftsmanship.[3] For example, invited model workers, industry masters and outstanding graduates from well-known enterprises to do lectures, exchange successful experiences and disseminate cutting-edge technologies and information so that college students can experience the charm of "big country artisans" in a distance; encourage students to actively participate in social production practices In order to build an exchange and practice platform for students, to learn from the first-line posts of enterprises and institutions, to inspire them to actively learn to be good, to continuously enrich their professional knowledge and consciously enhance their sense of social responsibility; to carry out "dedicated dedication , Excellence, focus on responsibility, innovation "as the theme of the four educational activities, through essay, speech, photo exhibition, vocational skills contest and other activities to create respect for labor, respect for skills, respect for refinement, respect for creating a strong culture of artisans, The formation of the mainstream campus culture so that students participate in activities at the same time feel the artisan culture, in the subtle influence of artisanal influence. Third, focus on home-school linkage, to achieve concerted efforts to educate people. Through the "Please come in, go out" approach, parents 'campus trips, home visits, parents' symposiums, parental correspondence and other activities were carried out to timely feedback school performance, obtain opinions and suggestions, broaden the two-way communication channels and realize a concerted effort to educate people at home and school.

\section{Conclusion}

Artisan spirit embodies the relentless pursuit of perfect things and noble personality, reflects people's pragmatic and innovative quality characteristics, but also shows the pursuit of excellence and self-realization of the good wishes, which is to promote the growth of college students has a very crucial incentive. Colleges and universities should closely follow the national development strategy of "Made in China 2025" so as to train students not only to have solid theoretical knowledge, but also to cultivate their professional dedication, excellence, dedication and daring to innovate, inspire them to constantly break themselves and calm themselves , Bravely face the challenges and difficulties, overcome impulsive psychology, devote themselves to learning the truth, and better serve the application of talent to serve the community.

\section{References}

[1] What Yuan Yu. On the application of undergraduate college students "craftsman spirit" training [J]. Student Forum, 2017 (5): 245,247.

[2] Li Fei, Tao Xiaoling. Applied undergraduate college students artisanal spirit cultivation [J]. Educational Observation, 2017 (6): 61-62.

[3] Wu Jin, Yang Yufeng. Applied long-term mechanism of "artisan spirit" cultivating in applied undergraduate colleges and universities [J]. Journal of Longyan University .2017 (35): 123-128. 